\title{
An Approach for Meeting Room Activity Monitoring and Analysis
}

\author{
Romans Taranovs ${ }^{1}$, Viktors Jesilevskis ${ }^{2}$, Gundars Miezitis ${ }^{3}$, Dmitrijs Bliznuks ${ }^{4}$, Eriks Klavins ${ }^{5}$, \\ Andrejs Kalnins ${ }^{6}$, Valerijs Zagursky ${ }^{7},{ }^{1,3,4,5,6,7}$ Riga Technical University, ${ }^{2}$ Accenture
}

\begin{abstract}
This paper presents the ongoing collaboration project between Riga Technical University and Accenture. The project is implemented by using recent technologies - Wireless Sensor Networks and Cloud Computing - to implement office room monitoring application that would make room utilization easier and more productive. The proposed system will provide administration with following information: how long and when the room is occupied, temperature, humidity, luminosity and $\mathrm{CO} 2$ concentration. The obtained information will be used to plan meetings, interviews, etc.
\end{abstract}

Keywords-Cloud computing, room monitoring, wireless sensor network.

\section{INTRODUCTION}

The presented paper presents the ongoing research within the collaborative project between the Riga Technical University and company Accenture. The Project is motivated by two problems:

a) decreased productivity while staying in a crowded room; b) errors in using room-scheduling service. Both problems lead to inefficient room usage. The paper and project are specifically focusing on meeting rooms and classrooms. The aim of the project is to create a solution that will allow to increase the room usage. The present paper is focused on the first stage of the project task specification, problem analysis and the survey of current situation. Let us start with the description and analysis of the first problem - bad health and mental productivity decrease in crowded unventilated rooms. Who might be affected by the described problem? The survey shows that almost $90 \%$ of office workers occasionally have the following problems: headache, noticeable decrease in mental abilities, fatigue, yawning. It may seem that these problems are typical and normal of hard working in office. However, medical research [4] shows that the cause of these problems is insufficient room ventilation that leads to high $\mathrm{CO}_{2}$ concentration in the air. This problem is especially noticeable in average size rooms with more than three people. Moreover, it arises more often during winter, when the windows are closed most of the time. Such situations are typical for lecture rooms and meeting rooms in companies. As could be seen from the results of medical research (Fig. 1), high $\mathrm{CO}_{2}$ concentration has the biggest impact on basic mental activities, initiative actions and strategic thinking.

All of the above mentioned applies to the situations when room ventilation is not sufficient. Therefore a question arises - how much ventilation is needed? It is impossible to have a universal solution, since each room has its own parameters. The $\mathrm{CO}_{2}$ concentration depends mainly on room size, ventilation and the number of people in it. Therefore it is necessary to find a solution for real time monitoring, that would raise the alarm, when the $\mathrm{CO}_{2}$ concentration reaches a critical level. As it is presented in further chapters, the existing solutions can measure the $\mathrm{CO}_{2}$ level and raise the alarm, but it is not possible to embed them into any other platform. Therefore we are proposing a wireless sensor network capable of measuring different kind of parameters, including $\mathrm{CO}_{2}$ concentration.

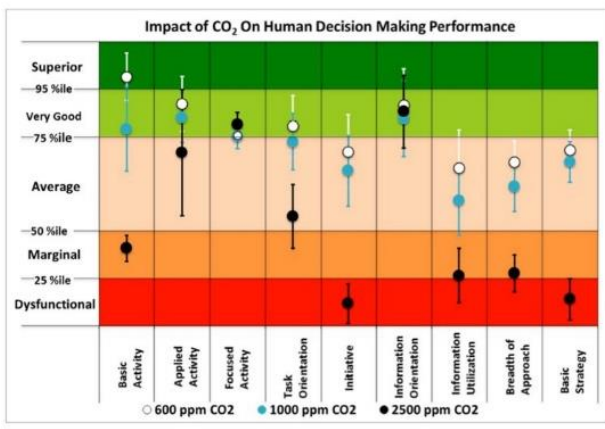

Fig. 1. Impact of $\mathrm{CO}_{2}$ on Human Decision Making Performance.

By using the wireless sensor network it is possible to create an open type scalable platform. Moreover, the proposed solution is not limited to air quality and room occupancy detection. Integration of sensor network with cloud based services allows to create a decentralized system that is able to deliver data for different kind of user end devices.

In order to create the proposed solution, the following tasks will be solved:

- Creating wireless access protocol;

- Integrating sensor network into the existing cloud service

Windows Azure;

- Enhancing sensor node energy efficiency;

- Realization of encrypted data transmission protocol.

\section{RELATED WORK}

There exist a variety of systems for indoor environment monitoring that have been proposed or developed in recent years. In this chapter we introduce readers to some of them.

[7] is a theoretical research on environment monitoring. The author provides necessary constraints and measured phenomena to implement structural, indoor and extreme event monitoring. For indoor environment monitoring temperature, humidity, true-light sensors, infrared-based presence sensors, and chemical sensors are useful and every environment monitoring application should consist of at least one of these sensors. It also points out that "interdisciplinary collaboration 
$2014 / 15$

between the researchers of computer science and structural engineering" is the key requirement for the monitoring of large public buildings.

The research in [8] was done by surveying more than 150 people in Europe and Asia and providing information of what environmental factors are important and how to present them to users, to build indoor environment monitoring system. The emphasis is put on designing easy to use and easy to understand user interface of such systems.

One example of environmental monitoring is the power consumption monitoring of buildings. [9] presents such an example. It provides a description of the power monitoring system in terms of implementation and use, as well as some examples of the benefits and savings that have been achieved through its use. By monitored values it calculates: (1) percentage of power use is calculated for each distribution panel and for each tenant; (2) tenant estimated energy cost per month to date; (3) estimated $\mathrm{CO}_{2}$ emission per month to date and (4) power use per unit area (watts per square foot). It is then used to identify and prioritize HVAC optimization programs, as well as to assess and quantify the effect of changes on energy consumption.

The Building Monitoring system based on Wireless Sensor Networks - BMWSN is presented in [9]. It is a clustering-based network specified for building environment monitoring. In this system temperature / humidity sensors (SHT11), light sensors (STL2550), and human detection sensors (BISS0001) are used. The cluster-heads perform data aggregation and form a tree hierarchy to forward the data to the server. The system implements simple alarm messaging to inform the user about exceeded environmental variables, but no active environment control is implemented.

[10] presents the development of a smart sensor network which allows the monitoring of the parameters in the workplace required for ergonomic assessment of working conditions. The phenomena measured are: temperature (TC1047A), humidity (HCH-1000), intensity of light (OPT101) and ambient noise (SPM0404LE5H-QB-38342). The proposed system is tested on a very small scale compared to the previous systems, but provides insight in how environmental parameters can be measured in workplace.

Besides distributed indoor environment monitoring systems there are other methods used for the same purpose. One such method is by using handheld devices. They are frequently referred to as "Indoor Environmental Quality" instruments. The price of such devices usually is an important drawback, because one such device can cost as much as several thousands of US dollars, furthermore, data often can be used only locally or in best case scenario saved on SD card. However, the positive feature of such devices is the accuracy and variety of sensors in such them. For example IEQ Check ${ }^{\mathrm{TM}}$ produced by Bacharach can use up to 7 different sensors - temperature, relative humidity and variation of Carbon Dioxide $\left(\mathrm{CO}_{2}\right)$, Carbon Monoxide (CO), Oxygen $\left(\mathrm{O}_{2}\right)$, Formaldehyde ( $\left.\mathrm{HCHO}\right)$, Total Volatile Organic Compounds (TVOCs), Nitrogen Dioxide (NO2), Nitric Oxide (NO), Sulfur Dioxide ( $\mathrm{SO}_{2}$ ), Ammonia $\left(\mathrm{NH}_{3}\right)$, Hydrogen Sulfide $\left(\mathrm{H}_{2} \mathrm{~S}\right)$ and Combustible Gases [11].
Other devices can even detect dust (even nano-scale) and measure airflow [16].

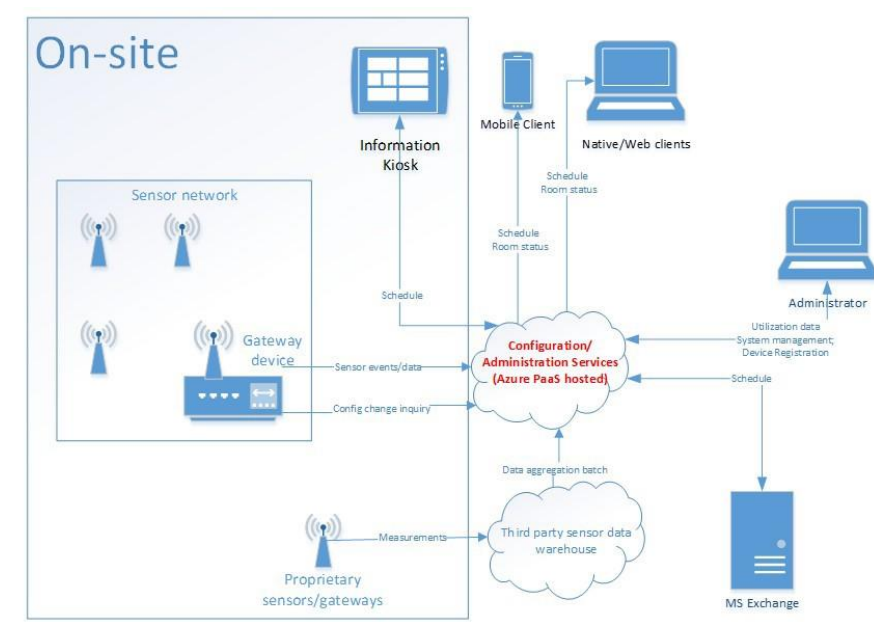

Fig. 2. Scheme for the proposed Internet of Things office environment monitoring solution.

\section{PRoposed System ARCHITECTURE}

As previous research shows none of the existing solutions can be reused entirely to be a solution for our research problem. Thus we have worked on a proposal and network architecture that might solve both problems: meeting room reservation vs. actual utilization monitoring and scalable solution for monitoring and analysis of office environment. Referring to Fig. 2 a scheme for the proposed Internet of Things office environment monitoring solution is depicted, the main parts of the system can be discussed. The system consists of two main parts: onsite distributed heterogeneous wireless sensor network and sensorial data storage and processing warehouse, formed using the cloud computing technology, here Azure provided cloud platform has been selected. On-site sensor network is heterogeneous because of three different types of heterogeneity:

- Communication protocols - in the current work we are combining different communication protocols. Sensorial data may be transferred via proprietary protocol stack and/or standard-based protocol stack. Here we are testing the interconnection of the highly-scalable WSN protocol stack designed by us with different standardized solutions, like ZigBee and Wi-Fi enabled nodes.

- Hardware of sensor nodes - since there are two ZigBee and Wi-Fi communication protocols based on standards presented it is obvious that the corresponding sensor nodes should have these standards enablement hardware. For instance to implement ZigBee communication sensor node should be equipped with IEEE 802.15.4 fully compatible radio chip. Likewise, to enable platform readiness for $\mathrm{Wi}$ Fi protocol stack corresponding devices should enable $802.11 \mathrm{~b} / \mathrm{g} / \mathrm{n}$ support in the hardware layer, too. Apart from these two examples the third one - the proprietary protocol stack cannot be so demanding on particular hardware since it should only satisfy the very basic software needs.

- Powering mode - mostly wireless sensor nodes are battery-powered devices. But in the current solution we have Netatmo Wi-Fi-enabled sensor nodes powered 
through battery as well via power line. Such combination is provided because of the architectural limitations of the solution: there is a GW and only some sensor nodes, normally only one per GW. ZigBee solution needs a different type of nodes, too. They are: coordinator, router and end device, where coordinator and router nodes with greater probability may need to be constantly powered because of the scenario they are fulfilling. Speaking about the proprietary WSN there might be both powering modes with different sensor nodes.

It is clear that sensorial data are being collected on a wireless sensor layer then transmitted to the cloud platform. Since we have three different technologies selected to be parts of WSN, the data transformation component should be provided. That component, here it is a Gateway, will gather data from one protocol stack and transform it to another one, here via TCP/IP protocol stack. Gateway modules (GW) are different for Netatmo WSN, for proprietary WSN and for Zigbee solutions. Since Netatmo sensor network solution in common consists of two nodes: the indoor one and the outdoor one, the GW for Netatmo is the same sensorial indoor module. The communication between these solution components, e.g. sensor nodes, is performed via Wi-Fi. Thus Netatmo is already TCP/IP-ready devices, which need to transfer the data to the generalization part of the system - the cloud computing platform. For that purpose one of sensor nodes is different by design and is statically line-powered. In the context of the proposed system we can call it a GW node. The Gateway node used for Zigbee network to access WAN and transmit data is constructed based on Raspberry Pi (RPi) device. An Xbee RF chip [12] connected to RPi forms interface to Zigbee WSN. Thus, RPi device here is performing a GW function: it has two different protocol stacks available on both physical and logic levels and its application is responsible for data retransmission from Zigbee network to TCP/IP till the cloud server. A more interesting solution in the whole proposed system is the proprietary version of wireless sensor network developed by us. From there on we would like to propose to use another architecture of office monitoring IoT solution, depicted in Fig. 3 where all three different technologies of the WSN layer are depicted as well as it is defined that all data are then gathered via REST API calls and stored on cloud server. Turning back to the solution based on our WSN approach it is valuable to mention that there are many points behind our solution proposition:

- The existing WSN layer solutions have multiple drawbacks like hard-to-scale architecture design, for instance Ne-tatmo solution can have one GW and maximum of four simple SNs. Similarly, Zigbee network topology is strictly defined and consists of predefined specific nodes that might be weak points of the whole system being points of failure.

Hardware solution limitation is another kind of drawback. Selecting some standard as basis for communication protocols we are strictly limited in using physical layers device components. For instance Zigbee solution demands to have RF chip that is IEEE 802.15.4 ready. With elimination of such drawback the WSN solution may be freely adopted for different environment conditions. For instance, if ISM bands are fully occupied with intense communication, we might choose the solution of the physical layer based on, e.g. $433 \mathrm{MHz}$ band.

TABLE I

COMPARISON OF TWO WSN DEVELOPMENT APPROACHES

\begin{tabular}{|c|c|c|}
\hline Name & Proposed solution & Standardized solution \\
\hline Usability & $\begin{array}{l}\text { Flexible amount of SNs in } \\
\text { a room }\end{array}$ & Use-cases are pre-defined \\
\hline Sensor variety & $\begin{array}{l}\text { Different sensor utilization } \\
\text { for monitoring purposes }\end{array}$ & Static sensor-wise solutions \\
\hline Protocol stack & $\begin{array}{l}\text { Communication protocols } \\
\text { can be chosen according to } \\
\text { current task }\end{array}$ & $\begin{array}{l}\text { Solutions are designed for } \\
\text { particular tasks and can be } \\
\text { reused in other } \\
\text { circumstances with possible } \\
\text { limitations }\end{array}$ \\
\hline Integration & $\begin{array}{l}\text { Fast integration with other } \\
\text { systems }\end{array}$ & $\begin{array}{l}\text { Pre-developed API as } \\
\text { integration and access } \\
\text { interface }\end{array}$ \\
\hline Costs & $\begin{array}{l}\text { Reduced costs due to } \\
\text { cheaper hardware }\end{array}$ & $\begin{array}{l}\text { Higher, because of already } \\
\text { produced hardware and } \\
\text { software }\end{array}$ \\
\hline Development time & Longer & $\begin{array}{l}\text { Shorter to longer if } \\
\text { additional features must be } \\
\text { implemented }\end{array}$ \\
\hline
\end{tabular}

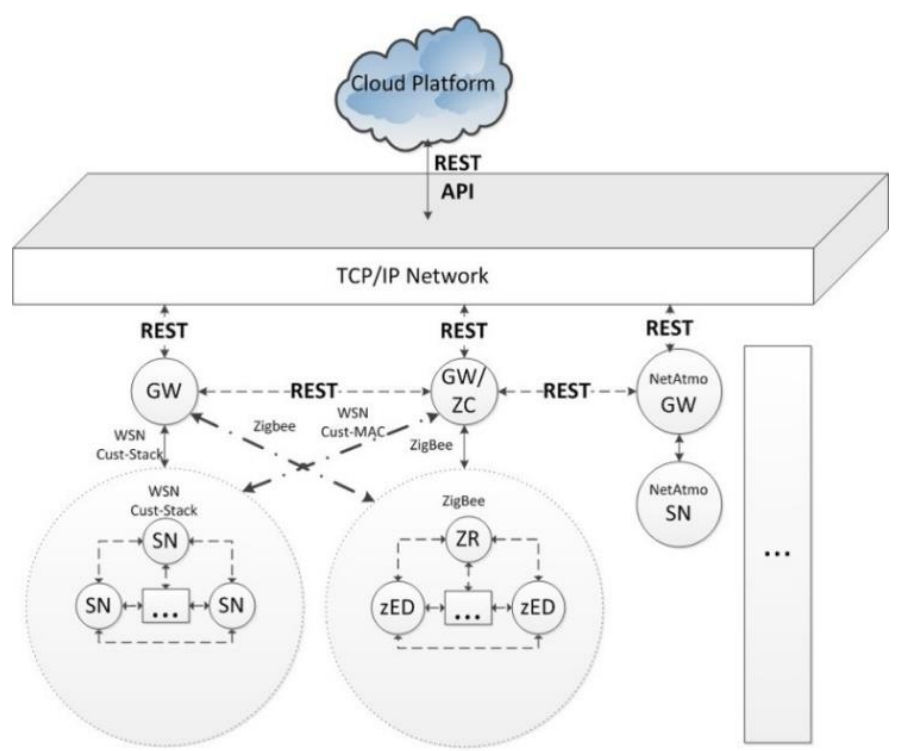

Fig. 3. The proposed architecture of office monitoring IoT.

- Application limitations are last but not least drawback that we have discovered. Proprietary solution gives maximal flexibility in choosing the application to run. For instance we can add any kind of sensor we need to fulfil a test. Apart from such possibilities the existing solutions frequently are some application oriented. For instance, Netatmo solution has embedded set of sensors that cannot be changed or extended without refactoring of the whole node.

Other points of different WSN development approaches can be found in Table I. Because of that we are going to focus mainly on our proposed proprietary WSN layer solution in the chapters of the next paper. 


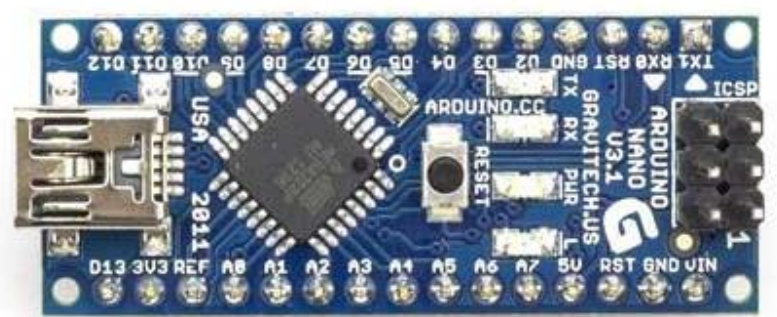

Fig. 4. Arduino Nano v3 module as basis for SN development.

\section{WSN LAYER IMPLEMENTATION}

\section{A. Development of Sensor Node}

We chose to use Arduino module under model name Nano v3 as basis module for SN. The module is depicted in Fig. 4. In the current SN version the functionality of each node should be ambient parameter monitoring with the help of three different sensors:

- Combined Temperature/Humidity sensor - DHT11 [13] low cost 1-Wire sensor with the precision of $2{ }^{\circ} \mathrm{C}$ and $5 \%$ RH. Connected to Arduino pins directly and with help of DHT11 library reads the sensorial data from the sensor.

- Light intensity sensor - BHT1750FVI [14] - easy to use soldered sensor with appropriate ready for development $\mathrm{C}++$ languages libraries.

- PIR Sensor - [15] - HC-SR501 - Motion detection sensor with variable period and cool down timer configurations. Useful in people movement detection tasks, for instance, we have used it for that purpose.

An application on each SN is necessary to deliver data to the cloud server. Thus, we have developed an all-in-one source code for any kind of version Nano module equipment. The crucial for sensor network is to establish Energy Saving operation.

\section{B. Energy Saving Operation}

The energy cost of transmitting a single bit of information is approximately the same as that needed for processing a thousand operations in a typical WSN [1]. The lifetime of a sensor network can be extended by jointly applying different techniques. For example, energy efficient protocols are aimed at minimizing the energy consumption during network activities. However, a large amount of energy is consumed by node components, CPU, radio, sensors, etc., even if they are idle. Power management schemes are thus used for switching off node components that are not temporarily needed [2]. NRF24L01 radio chips were used in this project. It consumes $12.3 \mathrm{~mA}$ receiving data at full speed ( $2 \mathrm{Mbps}$ on-air data-rate) and $11.3 \mathrm{~mA}$ sending data at $0 \mathrm{dBm}$. Using simple batteries with this transceiver, WSN will operate approximately for 35 hours if only communicating. WSN also consists of several sensors that also will consume battery energy, so it reduces lifetime to approximately 24 hours. Energy saving methods can extend WSN lifetime for more times. Using SLEEP/WAKEUP

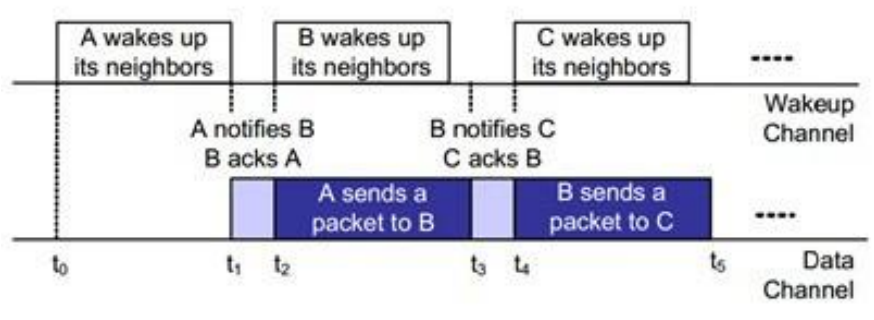

Fig. 5. Pipelined wakeup procedure in PTW.

protocol proposed in [2] it is possible that WSN will work for months without batteries change. WSN can use a Pipelined Tone Wakeup (PTW) scheme proposed in [3]. There are two different channels for wakeup signals and data. In wakeup channel transmits only wakeup tone to awake neighboring nodes. Let us suppose that node $\mathrm{A}$ has to transmit a data message to node $\mathrm{C}$ through node $\mathrm{B}$. At time $t_{0}$, A starts sending a wakeup tone over wakeup channel. This tone awakes all neighbors of A. At time $t_{1} \mathrm{~A}$ sends a notification packet to node $B$ on the data channel to inform that the next data packet will be destined to B. All neighbors of A, instead node B, learn that the following message is not intended for them and they turn off their data radio. Instead, $B$ realizes to be the destination of next data message, and replies with a wakeup acknowledgment on the data channel. After acknowledgement, A starts transmitting the data packet on the data channel. At the same time, B starts sending a tone on the wakeup channel to awake all its neighbors. As shown in Fig. 5, the packet transmission from $\mathrm{A}$ to $\mathrm{B}$ on the data channel, and the tone transmission of B on the wakeup channel are done in parallel. As the WSN will be used in offices with a known work-time, all nodes will work at this time. After the work-time all nodes power off all sensors and radio and then go to deep SLEEP mode. According to the office nodes will WAKEUP several minutes before work-time starts. The $\mathrm{CO}_{2}$ sensor can be disconnected from power or be connected only to make a few measurements of the air, and then again disconnected. This will give significant energy economy, because it is known that the air quality is best before work-time.

\section{Secure Communication}

To create a reliable system it is necessary to ensure data protection at all layers. Since wireless sensor nodes are limited in computational resources, it is not possible to use typical encryption. As a solution to existing problem it is possible to use Elliptic curve cryptography. It would allow establishing data protection comparable with typical encryption protocols like TLS, but using less computational resource. ECC-cryptographic schemes [5] are relying on scalar multiplication of elliptic curve points. For elliptic curves, the problem assumed to be intractable is finding the discrete logarithm of an element. Key in elliptic curve cryptography can be shorter, but still offer same security as RSA. For example, a 160-bit ECC key provides the same level of security as a 1024-bit RSA key, and a 224-bit ECC key provides the same security as a 2048-bit RSA key. Smaller keys mean faster computation, lower power consumption, and memory and bandwidth savings [6]. 


\section{CONCLUSION}

Since that is work-in-progress paper we have showed and checked the possibility to interconnect different technologies together with the common API. In the current situation we have different WSNs connected together forming heterogeneous WSN. The multi technology verification and configuration is done in the cloud. Such approach adds simplicity to GWs and SNs. As well WSN software designers are focused on sensorial use cases rather than on how to communicate between technology-different devices. Our investigation of the current situation shows that none of the existing solutions is that closed to our flexible and scalable solution. Apart from hat has been done, we have prepared a list of items we should cover in the next releases. Such tasks are: routing on WSN layer, security on all communication components, etc.

\section{REFERENCES}

[1] A. Giuseppe et al., "How to prolong the lifetime of wireless sensor networks," Mobile Ad Hoc and Pervasive Communications, 2006, pp. 1-26.

[2] A. Giuseppe et al., "Energy conservation in wireless sensor networks: A survey," Ad Hoc Networks 7.3, 2009, pp. 537-568.

[3] Y. Xue, N. F. Vaidya, "A wakeup scheme for sensor networks: Achieving balance between energy saving and end-to-end delay," Real-Time and Embedded Technology and Applications Symposium, 2004, Proc. RTAS 2004, 10th IEEE, pp. 19-26. http://dx.doi.org/10.1109/RTTAS.2004.1317245

[4] U. Satish, et al. "Is $\mathrm{CO}_{2}$ an Indoor Pollutant? Direct Effects of Low to Moderate $\mathrm{CO}_{2}$ Concentrations on Human Decision? Making Performance," Environmental health perspectives, 2014, pp. 1671-7. http://dx.doi.org/10.1289/ehp.1104789

[5] SEC1: Elliptic Curve Cryptography [Online]. [Accessed: 19 Oct. 2009]. Available: http://www.secg.org/sec1-v2.pdf

[6] Huge Advance for Tiny Devices [Online]. [Accessed: 19 Oct. 2009] Available: http://research.sun.com/spotlight/2005 02 10.tiny devices.htm

[7] M. Demirbas, "Wireless Sensor Networks for Monitoring of Large Public Buildings," 2005, pp. 605-634.

[8] S.-C. Chien, R. Zach, A. Mahdavi, "Developing user interfaces for monitoring systems in buildings," IADIS International Conference Interfaces and Human Computer Interaction 2011, 2011, pp. 29-36, ISBN: 978-972-8939-52-6.

[9] BLDG services group inc., "White paper Power Monitoring in an Office Building," Edmonton Alberta, Canada, 2011, p. 9.

[10] Q. Dong, L. Yu, H. Lu, Z. Hong, Y. Chen, "Design of Building Monitoring Systems Based on Wireless Sensor Networks," Wireless Sensor Network, 2010, 2, pp. 703-709. http://dx.doi.org/10.4236/wsn.2010.29085

[11] T. Trifonova, V. Markova, V. Draganov, K. Angelova, V. Dimitrov, "Smart sensor network for ergonomic evaluation of working environment," ICEST 2013, Ohrid, Macedonia, 2013, 1, pp. 371-375.

[12] XBee 802.15.4 - Digi International [Online]. [Accessed: 8 Nov. 2014]. Available: http://www.digi.com/products/wireless-wired-embedded-solutions/ zigbee-rf-modules/point-multipoint-rfmodules/xbee-series1-module\#toverview.

[13] DHT11 - Humidity and Temperature Sensor [3732], [Online]. Sunrom Technologies [Accessed: 8 Nov. 2014]. Available: http://www.sunrom.com/ p/dht11-humidity-and-temperature-sensor.

[14] Digital 16bit Serial Output Type Ambient Light Sensor IC [Online] [Accessed: 8 Nov. 2014]. Available: http://www.dfrobot.com/image/data/ SEN0097/BH1750FVI.pdf.
[15] HC-SR501 PIR motion detector [Online]. IEQ Chek, product description [Accessed: 8 Nov. 2014]. Available: http://www.mpja.com/download/ 31227 sc.pdf.

[16] IEQ Chek Features \& Benefits [Online]. [Accessed: 26 Oct. 2014]. Available: http://www.tequipment.net/assets/1/26/Documents/Bacharach/ 1510_0002/1510_0002_doc_1.pdf.

Romans Taranovs had received Master's Degree in 2007, Master's Degree in 2009 and Doctor's Degree in Computer Science in 2014 from Riga Technical University. Presently he is a research assistant with Computer Networks and System Technology Department of RTU. He is also a Lead development specialist with Accenture. His research interests are: self-organizing wireless sensor networks, embedded systems and cloud computing. He is an IEEE Student member since 2010. He has been involved in EU project Stratos and several Latvian Council of Science projects.

Email: romans.taranovs@rtu.lv

Viktors Jesilevskis received Master's Degree from Riga Technical University in 2004. He is currently a .NET lead architect with Accenture. His interests are: emerging technologies, cloud computing (Azure) and .NET platform.

Email: viktors.jesilevskis@accenture.com

Dmitrijs Bliznuks received Master's Degree from Riga Technical University in 2008. He is currently a $\mathrm{PhD}$ student with Faculty of Computer Science and Information Technology, Riga Technical University. Since 2009 he has been a researcher with Riga Technical University. His research interests include wireless networks and computer based control.

E-mail: dmitrijs.bliznuks@ @rtu.lv

Gundars Miezitis was born in 1987. He received Master's Degree in Computer Science from Riga Technical University in 2012. Presently he is a $\mathrm{PhD}$ student with Institute of Computer Control, Automation and Computer Science of the Department of Computer Networks and System Technology, Riga Technical University. His previous work includes research connected with Wireless Sensor Network localization problems and localization using radio signal strength.

Email: gundars.miezitis@ rtu.lv

Andrejs Kalnins received Master's Degree from Riga Technical University in 2012. Presently he is a PhD student with Riga Technical University. Since 2012 he has been a lecturer with the Faculty of Computer Science and Information Technology, Riga Technical University.

E-mail: andrejs.kalnins@rtu.lv

Eriks Klavins is a PhD student with the Faculty of Computer Science and Information Technology, Riga Technical University. He received Master's Degree in 2012. His research interests include: electronics, automatic control design and wireless sensor networks.

E-mail: klavins.eriks@rtu.lv

Valerijs Zagursky received Master's Degree in Computer Science from Riga Technical University in 1965 and the title of Candidate of Technical Science in Circuits and Systems in 1972 from Latvian Academy of Science, Doctor of Technical Science in 1990 from the Ukrainian Academy of Science and Dr. habil. comp. sc. in 1992 from the University of Latvia. He is a professor and Head of Department of Computer Networks and Systems Technology with RTU, as well as a member of the IEEE and ACM, as well as an expert with the Latvian Council of Science. His research interests include: networks, mixed signal system design, MAC protocols, resource scheduling, cross-layer design, cooperative functioning of systems, wireless ad hoc and sensor networks.

E-mail: vzagursky@gmail.com

\section{Romāns Taranovs, Viktors Jesilevskis, Gundars Miezitis, Dmitrijs Bliznuks, Ēriks Klavins, Andrejs Kalnins, Valerijs Zagurskis. Pieeja aktivitāšu} novērošanai un analīzei sanāksmju telpās

Šis raksts atspogulo sadarbības projektu starp Rīgas Tehnisko universitāti un uzṇēmumu Accenture. Projekts tiek īstenots, izmantojot jaunākās bezvadu sensoru tīklu un mākoṇskaitḷošanas tehnologijas. Projekta mērḳis ir īstenot biroja telpu monitoringa sistēmu, kas padarītu vieglāku un produktīvāku telpas izmantošanu. Piedāvātā sistēma nodrošina administrāciju ar sekojošu informāciju - kad un cik ilgi telpa būs aizņemta, temperatūru, mitrumu, spilgtumu un CO ${ }_{2}$ koncentrāciju. Šì informācija tiks izmantota, lai plānotu tikšanās, intervijas un citas darba aktivitātes. Pētījumi rāda, ka $\mathrm{CO}_{2}$ līmenis, kā arī citi vides parametri iespaido cilvēku darbspējas un vispārējo sajūtu. Tāpēc nepārtrauktā vides parametru detektēšana ir nepieciešama, lai laikus pieņemtu lēmumus situācijas uzlabošanai. Šai pieejai ir vairākas citas priekšrocības, tādas kā energoresursu efektīvas izmantošanas monitorings. Piemēram, pārrunu telpā paliek ieslēgts apgaismojums - tātad lieks elektroenerǵijas patēriņš. Mākoṇdatošana šādās bezvadu sensoru sistēmās kalpo kā centrālais datu savākšanas un apstrādes punkts. Pateicoties šai tehnologijiai, sensoru dati paliek pieejami no vairākām ierīcēm un caur vairākām tehnologíijām. Kā arī datu apstrādi var krietni paātrināt, papildus pieliekot dinamisku skaitḷošanas jaudu. 
$2014 / 15$

Роман Таранов, Виктор Ясилевский, Гундарс Миезитис, Дмитрий Близнюк, Эрикс Клявиньш, Аидрей Калныньш, Валерий Загурский. Подход к анализу и наблюдениям за помещениями собраний.

В данной статье представлен действующий проект сотрудничества между Рижским техническим университетом и Accenture. Проект предполагает использование современных технологий - Беспроводных Сенсорных сетей и Облачной платформы для реализации контроля (мониторинга) использования офисных помещений, что обеспечит более эффективную эксплуатацию помещений. Предлагаемая система обеспечит администрацию следующими данными: как давно и как долго помещение было занято, температура, влажность, освещённость и концентрация углекислого газа в помещении. Вся предоставляемая информация будет использоваться для планирования встреч, интервью и т.д. Исследования показывают, что уровень $\mathrm{CO}_{2}$, а также другие параметры среды влияют на работоспособность и общее состояние человека. Поэтому необходим непрерывный мониторинг и выявление изменений этих параметров для своевременного принятия решений для улучшения ситуации. Также у данного подхода имеются дополнительные возможности, такие, как контроль за эффективностью использования энергоресурсов. К примеру, в помещении для переговоров оставлено включённым освещение - выявлено нерациональное и излишнее использование электроэнергии. Облачные вычисления в подобных беспроводных сенсорных системах служат как центральные узлы сбора и обработки данных. Благодаря данной технологии, сенсорные данные доступны с разных устройств/платформ, использующих разные технологии. К тому же обработка данных может быть существенно ускорена из-за динамической расширяемости вычислительных ресурсов. 